\title{
The Role of Managers' Ethical Leadership Behaviour on Hotel Employees' Perception of Organizational Justice
}

\author{
Cenk Murat KOÇOĞLU (iDa Yurdanur YUMUK iDb \\ aKarabük University, Safranbolu Tourism Faculty, Karabük, Turkey. cenk-murat@hotmail.com \\ b yarin58@hotmail.com
}

\begin{tabular}{ll}
\hline ARTICLE INFO & ABSTRACT \\
\hline Keywords: & $\begin{array}{l}\text { Purpose - The purpose of the research is to reveal the role of managers' ethical leadership } \\
\text { behaviours on the employees' perceptions of organizational justice in five-star hotels in Ankara. } \\
\text { Ethical Leadership } \\
\text { Organizational Justice } \\
\text { Design/Methodology/Approach - Quantitative research method was used and it was benefited } \\
\text { from questionnaire technique in data gathering in this study. Data was gathered by means of a } \\
\text { questionnaire from } 398 \text { participating employees working in } 9 \text { five-star hotel businesses in } \\
\text { Ankara. }\end{array}$ \\
Received 20 December 2018 & $\begin{array}{l}\text { Findings: It was determined that managers exhibited behaviours within the framework of } \\
\text { ethical principles and this situation affected the employees' perception of justice positively in }\end{array}$ \\
Revised 20 February 2019 & $\begin{array}{l}\text { the organization. Also, it was suggested that ethical leadership behaviour affected distributive } \\
\text { justice mostly. } \\
\text { Accepted } 8 \text { March 2019 }\end{array}$ \\
Discussion - It is thought that the research will make contributions to hotel managers about \\
human resources management. The important limitation of the research constituted that it was \\
only conducted on the hotel employees in five-star hotels in Ankara. For future researches, it \\
will be beneficial that determining different destinations and tourism establishments as \\
application field will provide opportunity for evaluate the topic thoroughly.
\end{tabular}

\section{Introduction}

Gaining a competitive advantage in tourism is not only related to touristic products but also service quality. Service quality is the perception for knowledge, skill, attitudes and behaviours of the human resources. Because of high labour turnover in tourism industry, positive perceptions about working conditions effect the recruitment process positively. Salary, bonus, social security, promotion and working conditions are some of the motivational factors. But, employees also consider that a management mentality based on ethical values and principles should be adopted. Perception of justice affects employee commitment positively in the organizations having a fair reward and punisment system. According to employees, decisions should be taken in accordance with justice and equality; the relation between employee and manager should be maintained within the scope of love, respect and honesty.

Accordingly, the purpose of the research is to reveal the role of managers' ethical leadership behaviours on the employees' perceptions of organizational justice in five-star hotels in Ankara. There are limited research in tourism area in contrast to several research in the foreign and domestic literature on the topic. Hence, it is thought that the research will contribute the tourism literature.

\section{Conceptual Framework}

Perception of organizational justice, ethical leadership behaviour and the relation between two concepts are explained within the context of conceptual framework.

\section{Organizational Justice}

Justice is a whole system accepting that every individual has fundamental freedoms and equal rights (Taylor, 2003: 211). This concept has transformed into organizational justice" meaning fair distribution of

\section{Suggested Citation:}

Koçoğlu, C.M., Yumuk, Y. (2019). The Role of Managers' Ethical Leadership Behaviour on Hotel Employees' Perception of Organizational Justice, Journal of Business Research-Turk, 11 (1), 337-346. 
rights gained in organization in time (İşbaşı, 2001: 60). Empirical researches indicate that organizational justice is a significant matter because of being related to organizational processes and results (Demir, 2011: 205). Perception of organizational justice is a judgement that individuals evaluate the attitudes and behaviours towards themselves in terms of fairness in the organization. As a consequence of the judgement, they develop an attitude towards organization and job (Meydan et al., 2011: 46). Perception of organizational justice is an important source of motivation for employees. Employees who think that unfair policies, procedures and practices are used in the organization lose their motivation and they intent to leave the organization as soon as possible (Parker and Kohlmeyer 2005: 357).

Organizational justice, an evaluation process regarding managerial decisions, is comprised of three dimensions; distributive justice, procedural justice and interactional justice (Searle and Ball, 2004: 710). Distributive justice refers to behaving fairly in the process of distributing rewards in the organizations. Distributive justice is based on "equity theory" by Adams who considers that rewards should be given in accordance with performance ( $\mathrm{Wu}$ and Wang, 2008: 183). Distributive justice is related to sharing of acquired rights as well. These acquirements are sometimes rewards, promotion, status and salary; sometimes sanctions such as punishment. Employees always compare the acquirements with their colleagues and as a result of the comparison, a perception concerning the justice balance develops in the organization. Perception of justice increases job performance and work commitment; perception of injustice decreases productivity and prompts employee to leave the organization (İşcan and Naktiyok, 2004: 187-188).

Procedural justice, the second dimension of organizational justice, relates to taking distributive decisions. Perceived justice and equality regarding decision procedures affect the attitude and behaviours in organization. Procedural justice states whether the procedures and policies determined by managers are fair or not unlike distributive justice limited with materialistic expectations (Jahangir et al., 2006: 23). Positive results developing in line with perceived justice depend that decisions should be consistent and unbiased. Employees' opinions should be received during the process of making decisions. The process of making decisions should be based on valid information and ethical values (İçerli, 2010: 82).

Interactional justice suggested by Bies and Moag (1986: 43-44) is simply a phenomenon concerning the quality of interpersonal relations in organizations. It explains the attitudes and behaviours of the managers towards employees when organizational procedures are applied. It is expected to be respectful and honest towards employees and they are appreciated in interactional justice having the characteristics of human and social (Greenberg, 1990: 411). Bies and Moag (1986) determined four criteria defining interactional justice. Respect is being polite instead of rude. Propriety refers to not asking inappropriate questions and making comment in a biased way. Truthfulness refers being honest instead of deceptive. Justification refers to informing about the decisions taken clearly and satisfyingly.

\section{Ethical Leadership}

Ethics is the principles, values and standarts indicating what is good and right and how people should live. Ethics is related to moral choice and standarts individual or organization oriented (Conaway and Fernandez, 2000: 26). Leadership states guiding a group or organizational members for achieving goals (Haq, 2011: 2793). The concept of ethics needs to be examined in terms of affecting the leaders' tasks. Researches conducted about ethics emphasize right, wrong, good, bad, virtue, responsibility, obligation, right and justice concepts and they indicate that human relations should be based on ethical principles (Ciulla, 2005: 326). Leaders play a significant role in dispensing justice depending on their statutory authority and power to take decision in the organization. Leaders have the opportunity to create a workplace environment that employees can perceive fairness about decisions in.

Ethical leadership is defined as "exhibiting normative attitude in human relations and organizational activities and supporting the attitude through two-way communication, empowerment and decision making" (Brown et al., 2005: 119-120). How the work should be done is decided in accordance with norms and standards in ethical leadership. It is discussed that whether work is ethical or not without considering the usefulness of it (Bolat and Seymen, 2003: 6). Honesty, loyalty, trustworthiness and considering organizational cooperation are the characteristics of ethical leaders (Peterson, 2002: 313). Ethical leadership differs from the other leadership types in terms of ethical content. For instance, although transformational leadership has an ethical dimenson; ethical leadership comprises the concept of ethics completely. Ethical 
leadership contributes to individuals to learn with the concepts of punishment and reward unlike other kinds of leadership (Mayer et al., 2009: 1).

Ethical leadership behaviour paves the way for ethical climate and positive organizational behaviours (Peterson, 2002: 313). Employee believing that organizational activities are performed within the scope of ethics; some matters like employment and performance assessment are carried out in accordance with ethical principles becomes highly committed to the organization (Thoms, 2008: 422; Zhu et al. , 2004). Interaction between organization members and manager in the leading position especially in service industry affects labour turnover positively or negatively (Kim and Brymer, 2011: 1025). Khuong and Quoc (2016) reveal that ethical leadership behaviour and perception of organizational justice affect employee performance positively.

\section{The Relationship Between Perception Of Organizational Justice And Ethical Leadership Behaviour}

Organizational members consider that leaders should take an ethical stance and they should determine organizational activities taking account of social values. Only if leaders treat impartial and fairly, ethical leadership emerges (Zhu et al., 2004: 17). Perception of organizational justice plays a significant role on leadership. For instance, subordinates who put all their cards on the table see their superiors as ethical leaders (Pillai et al., 1999: 765-766). Ethical leaders try to create ethical climate and determine some rules and procedures for employee (Yeşiltaş et al., 2012: 22). Mayer et al. (2012: 157) emphasized that treating employee fairly as an indication of ethical leadership overlaps with interactional justice; so, there is a relationship between ethical leadership and organizational justice.

There are various researches revealing that there is a positive relationship between ethical leadership behaviour and perception of organizational justice in the literature. It was ascertained that manager's ethical leadership behaviour had positive effect on employee perception of organizational justice on blue-collar workers by (Kurgun et al., 2013). Çıraklı et al. (2014) determined that ethical leadership behaviour affected perception of organizational justice (mostly interactional justice) positively in the research, population was health professionals in state hopitals. The research by Akatay et al. (2016) indicated that ethical leadership behaviour affected organizational justice positively. Bağcı and Akbaş (2018) ascertained that ethical leadership behaviour had positive effect on each dimension of organizational justice. Also, it was found that ethical leadership behaviour explained interactional justice mostly and distributive justice at least.

There are some researches conducted regarding the topic on tourism. According to research by Yeşiltaş et al. (2012); it was seen that there was a strong positive relationship between ethical leadership and perception of organizational justice in four and five-star hotels in İstanbul. Öktem (2013) found that managers' ethical leadership behaviour affected the perception of organizational justice in travel agencies and hotels. İnak et al. (2018) determined that there was a positive relationship between ethical leadership behaviour and perception of organizational justice in three, four and five-star hotels in Nevşehir.

Depending on the researches in the literature, the following hypotheses were developed:

$\mathbf{H}_{1}$ : Managers' ethical leadership behaviours affect hotel employees' perceptions of organizational justice positively.

H1a: Managers' ethical leadership behaviours affect hotel employees' perceptions of distributive justice positively.

Hib: Managers' ethical leadership behaviours affect hotel employees' perceptions of procedural justice positively.

H1s: Managers' ethical leadership behaviours affect hotel employees' perceptions of interactional justice positively.

\section{Methodology}

Quantitative research method was used and it was benefited from questionnaire technique in data gathering in this study. The purpose of this research is to determine the effect of ethical leadership behaviour on perceptions of organizational justice and subdimensions. 


\section{Data Gathering Tool}

Literature review was conducted regarding topic and questionnaire form was prepared by using ethical leadership scale consisting of 10 statements and one dimension by Brown et al. (2005); organizational justice scale consisting of 20 statements and three dimensions by Niehoff and Moorman'e (1993). Also, 7 questions for demographic information were included. Questionnaire form consists of 3 sections. First, scales were prepared to 5 point likert scale (1-Strongly disagree, 5-Stronly agree). Ouestionnaire forms were conducted on 396 hotel employees in five-star hotels in Ankara. The linguistic validity of the scale was proved. Therefore, no changes were made about questionnaire form.

\section{Population and Sample}

Population of the research constitutes the hotel employees in five-star hotels in Ankara. Ankara was selected as population because of having several city hotels and the hotels render service thoroughout 12 months. Ankara is also a favourable destination in terms of congress and meeting tourism and many tourism amenities are in service. Five-star hotels were determined as population of the research because it was thought that five- star hotels were large-scale organizations and they had corporate structure (Akova and Işık, 2008). According to Ministry of Culture and Tourism (2018); there are 26 five-star hotels and 10872 beds in Ankara. Number of the employees couldn't be reached definitely. Therefore, for determining the population of the research, it was benefited from employee rate $(0,59)$ per bed in five-star hotels in the literature (Erdem, 2004: 48). Population of the research constitutes 6414 employees in the five-star hotels. Convenience sampling method was used as sampling method in the research. For determining sample size, Sekaran (1992) suggests that sample size of 384 for $95 \%$ confidence intervals is sufficient in case of population size about one million and above. 398 questionnaire forms (79 \%) were returned of 500 ones from 9 hotel businesses accepting to participate in the survey and 2 questionnaire forms weren't assessed because of missing data.

\section{Research Model}

According to research model, ethical leadership behaviour has positive effects on perception of organizational justice and subdimesions; distributive justice, procedural justice and interactional justice in hotel businesses. It was benefited from the researches in literature for developing research model and hypotheses.

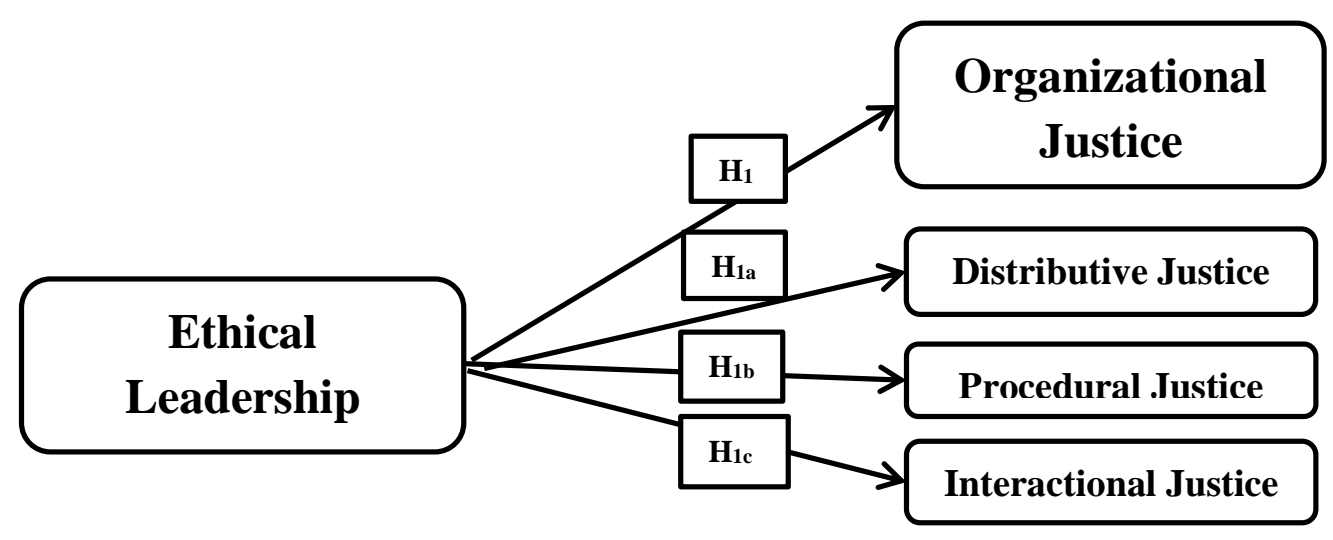

Figure 1: Research Model

\section{Findings}

Demographic attributes of employees, exploratory factor analysis for ethical leadership and organizational justice scales and regression analysis regarding variables are included in this section. 
Table 1: Demographic Attributes of Employees

\begin{tabular}{|c|c|c|c|c|c|}
\hline Gender & Frequency & Percent & Education & Frequency & Percent \\
\hline Female & 192 & 48,5 & Primary Education & 34 & 8,6 \\
\hline Male & 204 & 51,5 & High School & 97 & 24,5 \\
\hline Total & 396 & 100,0 & Associate Degree & 131 & 33,1 \\
\hline Age & Frequency & Percent & Bachelor's Degree & 120 & 30,3 \\
\hline $18-26$ & 92 & 23,2 & Postgraduate & 14 & 3,5 \\
\hline $27-35$ & 151 & 38,1 & Total & 396 & 100,0 \\
\hline $36-44$ & 97 & 24,5 & Department & Frequency & Percent \\
\hline $45-53$ & 47 & 11,9 & Front office & 93 & 23,5 \\
\hline $54-62$ & 9 & 2,3 & Housekeeping & 90 & 22,7 \\
\hline Total & 396 & 100,0 & Food and Beverage & 110 & 27,8 \\
\hline Income & Frequency & Percent & Kitchen & 41 & 10,4 \\
\hline $2000 \mathrm{TL}$ and below & 23 & 5,8 & Other & 62 & 15,7 \\
\hline $2001-3000 \mathrm{TL}$ & 102 & 25,8 & Total & 396 & 100,0 \\
\hline $3001-4000 \mathrm{TL}$ & 139 & 35,1 & Tenure & Frequency & Percent \\
\hline $4001-5000 \mathrm{TL}$ & 73 & 18,4 & Less than 1 year & 75 & 18,9 \\
\hline $5000 \mathrm{TL}$ and above & 59 & 14,9 & $1-3$ years & 153 & 38,6 \\
\hline Total & 396 & 100,0 & 4-6 years & 128 & 32,3 \\
\hline Position & Frequency & Percent & $7-10$ years & 28 & 7,1 \\
\hline Lower echelon & 241 & 60,9 & 11 years and above & 12 & 3,0 \\
\hline Mid level & 120 & 30,3 & Total & 396 & 100,0 \\
\hline Upper tier & 35 & 8,8 & & & \\
\hline Total & 396 & 100,0 & & & \\
\hline
\end{tabular}

According to Table 1; 97 employees are between 36-44 ages and 9 employees are between 54-62 ages. When considering education level; more than half of the employees are associate degree (131) and bachelor's degree (120). Most of the employees (241) have 2001-4000 TL income. 28 percent (110) of the employees work in the food and beverage department; \%23,5 percent (93) in the front office department and \%23 percent (90) in the housekeeping department. According to tenure; most of them (153) work between 1-3 years. 61 percent (241) are lower echelon employees.

\section{Exploratory Factor Analysis For Ethical Leadership and Organizational Justice Scales}

Explanatory factor analysis was carried out for revealing the dimensions of ethical leadership and organizational justice scales and determining the validity and reliability of them. The reliability analyses were made for ethical leadership and organizational justice scales. The Cronbach Alpha reliabilities, in turn, were 0,93 and 0,94 .

Table 2: Exploratory Factor Analysis For Ethical Leadership and Organizational Justice Scales

\begin{tabular}{|c|c|c|c|}
\hline Statements & $\begin{array}{c}\text { Factor } \\
\text { Loading }\end{array}$ & $\begin{array}{c}\text { Variance } \\
\%\end{array}$ & $\begin{array}{c}\text { C.Alph. } \\
\alpha\end{array}$ \\
\hline \multicolumn{2}{|l|}{ Ethical Leadership } & \multirow{11}{*}{61,84} & \multirow{11}{*}{,929 } \\
\hline My manager behaves ethically in their personal life. & 851 & & \\
\hline My manager tries to make a decision honestly and fairly. & 849 & & \\
\hline My manager wants to protect employees' benefits ideally. & 833 & & \\
\hline My manager exhibits ethical behaviours and set employees an example. & 826 & & \\
\hline My manager shares business ethics and ethical values with employees. & 810 & & \\
\hline My manager is trustee. & ,781 & & \\
\hline My manager listens employees' ideas. & ,759 & & \\
\hline My manager describes "success" not only via results, but also tracks. & ,758 & & \\
\hline My manager gets employees' opnions about things to do. & ,720 & & \\
\hline My manager applies disciplinary rules about unethical behaviours. & 654 & & \\
\hline \multicolumn{4}{|c|}{$\begin{array}{l}\text { Principal Component Analysis, Components Extracted, Kaiser-Meyer-Olkin Measure of Sampling Adequacy: } \\
0,899\end{array}$} \\
\hline
\end{tabular}




\begin{tabular}{|c|c|c|c|}
\hline Organizational Justice & $\begin{array}{l}\text { Factor } \\
\text { Loading }\end{array}$ & $\begin{array}{l}\text { Variance } \\
\%\end{array}$ & $\begin{array}{l}\text { C.Alph. } \\
\alpha\end{array}$ \\
\hline \multicolumn{2}{|l|}{ Interactional Justice } & \multirow{10}{*}{33,99} & \multirow{10}{*}{,946 } \\
\hline My manager gives sufficient justifications for the decisions regarding my job. & 856 & & \\
\hline $\begin{array}{l}\text { My manager makes conceivable statements during the process of making } \\
\text { decisions about my job. }\end{array}$ & , 828 & & \\
\hline $\begin{array}{l}\text { My manager is sensitive to my personel needs during the process of making } \\
\text { decisions about my job. }\end{array}$ & 803 & & \\
\hline My manager announces every decision about my job. & ,794 & & \\
\hline $\begin{array}{l}\text { My manager protects my rights during the process of making decisions about } \\
\text { my job. }\end{array}$ & 793 & & \\
\hline $\begin{array}{l}\text { My manager is honest and sincere during the process of making decisions } \\
\text { about my job. }\end{array}$ & 791 & & \\
\hline My manager discusses with me the decisions about my job. & ,785 & & \\
\hline $\begin{array}{l}\text { My manager considers me and acts respectfully during the process of making } \\
\text { decisions about my job. }\end{array}$ & 773 & & \\
\hline $\begin{array}{l}\text { My manager does me proud during the process of making decisions about my } \\
\text { job. }\end{array}$ & 749 & & \\
\hline \multicolumn{2}{|l|}{ Distributive Justice } & \multirow{6}{*}{24,32} & \multirow{6}{*}{,942 } \\
\hline My work load is fair. & 900 & & \\
\hline My acquirements are fair. & ,872 & & \\
\hline My work responsibilities are fair. & 840 & & \\
\hline My salary is fair. & 835 & & \\
\hline My work schedule is fair. & ,834 & & \\
\hline \multicolumn{2}{|l|}{ Procedural Justice } & \multirow{5}{*}{12,83} & \multirow{5}{*}{,710 } \\
\hline $\begin{array}{l}\text { My manager gathers complete and accurate information before making } \\
\text { occupational decisions. }\end{array}$ & ,747 & & \\
\hline All of the occupational decisions are applied without discriminating. & 663 & & \\
\hline $\begin{array}{l}\text { My manager takes employees' opinions before making occupational } \\
\text { decisions. }\end{array}$ & 634 & & \\
\hline $\begin{array}{l}\text { My manager explains the decisions taken to the employees and gives } \\
\text { additional info on demand. }\end{array}$ & 633 & & \\
\hline
\end{tabular}

According to exploratory factor analysis for ethical leadership in Table 2; Kaiser Normalization in exploratory factor analysis, factors with eigenvalue greater than 1.0 were considered. It was stated that the scale consisted of one dimension. It was seen that the total variance percentage was 61,84 . Because of the percentage more than 50\%, the result was accepted as valid (Scherer et al., 1988).

As a result of exploratory factor analysis for organizational justice, 2 statements of procedural justice were eliminated from the analysis. Because, one's factor loading was less than $40 \%$ and the other was overlap. When considered the factors with eigenvalue greater than 1.0 to Kaiser Normalization; it was stated that the scale consisted of 3 dimensions. It was seen that the total variance percentage was 71,14 . According to the reliability analysis, the reliability values of the dimensions; $95 \%$ for interactional justice, $94 \%$ for distributive justice and $71 \%$ for procedural.

Table 3: Means of Ethical Leadership and Organizational Justice Scales

\begin{tabular}{|c|c|c|}
\hline Dimensions & Mean & S. Deviation \\
\hline Ethical Leadership & 3,46 &, 86696 \\
\hline Organizational Justice & 3,48 & ,77096 \\
\hline Distributive Justice & 3,38 & 1,05113 \\
\hline Procedural Justice & 3,38 & ,88336 \\
\hline Interactional Justice & 3,58 & ,88336 \\
\hline
\end{tabular}

The means of ethical leadership, organizational justice and subdimensions are included in Table 3 . When examining the means; the means of ethical leadership and organizational justice, in turn, are 3,46 and 3,48. 
Dimension having the highest mean is "interactional justice" $(3,58)$. "Procedural justice" and "distributive justice" have same mean values $(3,38)$. Thus, it is stated that the hotel managers have ethical leadership behaviours and accordingly, employees develop perception of organizational justice. Also, it is clearly seen that there is a fair reward and punishment system in the organization; the relationships between managers and employees are within the frame of value, respect and honesty and the decisions taken in the organization are shared with employees.

\section{The Effect of Ethical Leadership Behaviour on Perception of Organizational Justice and Subdimensions}

Table 4: The Effect of Ethical Leadership Behaviour on Perception of Organizational Justice and Subdimensions

\begin{tabular}{|l|c|c|c|c|c|c|c|}
\hline Models & Independent Variable & Dependent Variable & Beta & $\mathbf{t}$ & $\mathbf{P}$ & $\mathbf{R}^{\mathbf{2}}$ & $\mathbf{F}$ \\
\hline Model 1 & Ethical Leadership & Organizational Justice &, 636 & 16,375 &, 000 &, 405 & 268,15 \\
\hline Model 2 & Ethical Leadership & Distributive Justice &, 579 & 14,079 &, 000 &, 335 & 198,23 \\
\hline Model 3 & Ethical Leadership & Procedural Justice &, 505 & 11,625 &, 000 &, 255 & 135,14 \\
\hline Model 4 & Ethical Leadership & Interactional Justice &, 508 & 11,706 &, 000 &, 258 & 137,02 \\
\hline
\end{tabular}

Simple linear regression for determining the effects of ethical leadership behaviour on perception of organizational justice and subdimensions is included in Table 4. According to model 1; simple linear regression made for determining the effect of ethical leadership behaviour on perception of organizational justice was found statistically significant $(F=268,15 ; p=, 000)$. Ethical leadership behaviour explains 40,5 percent of perception of organizational justice. When examining t-tests regarding standardized regression coefficients and significance of regression coefficients, It was ascertained that ethical leadership behaviour had a significant positive effect on perception of organizational justice $\left(\mathrm{H}_{1}, \beta=, 636 ; p=, 000\right)$ and $\mathrm{H}_{1}$ was accepted.

According to model 2; simple linear regression made for determining the effect of ethical leadership behaviour on distributive justice was found statistically significant $(F=198,23 ; p=, 000)$. Ethical leadership behaviour explains 33,5 percent of distributive justice. When examining t-tests regarding standardized regression coefficients and significance of regression coefficients, It was ascertained that ethical leadership behaviour had a significant positive effect on distributive justice $\left(\mathrm{H}_{1 a}, \beta=, 579 ; \mathrm{p}=, 000\right)$ and $\mathrm{H}_{1 a}$ was accepted.

According to model 3; simple linear regression made for determining the effect of ethical leadership behaviour on procedural justice was found statistically significant $(F=135,14 ; p=, 000)$. Ethical leadership behaviour explains 25,5 percent of procedural justice. When examining t-tests regarding standardized regression coefficients and significance of regression coefficients, It was ascertained that ethical leadership behaviour had a significant positive effect on procedural justice $\left(\mathrm{H}_{1 b}, \beta=, 505 ; \mathrm{p}=, 000\right)$. Hence, $\mathrm{H}_{1 b}$ was accepted.

According to model 4; simple linear regression made for determining the effect of ethical leadership behaviour on interactional justice was found statistically significant $(F=137,02 ; p=000)$. Ethical leadership behaviour explains 25,8 percent of interactional justice. When examining t-tests regarding standardized regression coefficients and significance of regression coefficients, It was ascertained that ethical leadership behaviour had a significant positive effect on interactional justice $\left(\mathrm{H}_{1}, \beta=, 508 ; \mathrm{p}=0.000\right)$. Hence, $\mathrm{H}_{1 \mathrm{c}}$ was accepted.

In parallel with these findings, it is appear that managers' ethical leadership behaviours affect employees' perceptions of organizational justice positively. Managers behaving in an ethical manner in hotel businesses create a fair work environment; perception of organizational justice affects the attitude and behaviours in the organization positively.

\section{Discussion and Conclusion}

The purpose of the research was to reveal the role of managers' ethical leadership behaviours on the employees' perceptions of organizational justice in five-star hotels in Ankara. It was determined that managers exhibited behaviours within the framework of ethical principles and this situation affected the employees' perception of justice positively in the organization. Also, it was suggested that ethical leadership behaviour affected distributive justice mostly. So, employees think that the organization has a fair punishment and reward system; the acquirements and sanctions are equal to their colleagues. The other 
organizational justice dimensions explained by ethical leadership behaviour are interactional justice and procedural justice. Thus, the relationship between employees and superiors keeps within the framework of respect, love and honesty. Employees believe that their opinion and suggestions are taken in the process of decision making and the decisions are shared with themselves clearly and satisfyingly. Some researches in the literature (Bağcı and Akbaş, 2018; İnak et al. , 2018; Kurgun et al. , 2013; Öktem, 2013) support the result.

Perception of organizational justice affects employee attitude and behaviours positively or negatively. Customer satisfaction in tourism industry aiming to serve human considerably depends on employee satisfaction. Individuals who believe that working conditions are fair stay as a member of the organization and show high performance. Simons and Roberson (2003) reveal that perceptions of procedural and interactional justice affect organizational commitment and volunteer behaviours positively, but they have negative effect on intention to leave the job in the research conducted on hotel employees working in different departments. Tang et al. (2015) ascertained that there was a positive relationship between ethical leadership behaviour and leader-member value congruence; there was a negative relationship between intention to leave and leader-member value congruence in the research conducted on restaurant employees in China. Also, it was stated that value congruence had a mediating role on the relationship between ethical leadership behaviour and intention to leave the job. It is inferred from the research on restaurant employees that there is a positive relationship between procedural justice and ethical climate and perception of procedural justice enhance performance and employee-customer interaction by Luria and Yagil (2008).

In accordance with the research results in the literature; it is possible to make some practical suggestions for managers. First, managers should take care of the congruence between the knowledge, skill and abilities of the candidates and the position requirements during recruitment. Specific and measurable performance criteria should be determined in organizations and a fair performance evaluation system should be used. Punishments and rewards should be given in accordance with employee performance. Employees should be counted in the decision-making process. New thoughts and ideas that will provide a competitive advantage should be promoted by increasing employee authority and responsibilities.

It is thought that perceived justice affects service quality positively in tourism organizations in which human resourches become more functional day by day. When considering structural features of tourism industry; psychological counselling services unit should be founded for solving the problems of the employees in the organizations; control mechanism should be constituted for protecting employee rights and professional laws explaining professional qualifications and standarts should be enacted (Yumuk, 2018: 176).

The important limitation of the research constituted that it was only conducted on the hotel employees in five-star hotels in Ankara. For future researches, it will be beneficial that determining different destinations and tourism establishments as application field will provide opportunity for evaluate the topic thoroughly. The research was conducted in city hotels. It is thought that repeating the research in resort hotels will suggest different results.

\section{References}

Akatay, A., Yücekaya, P. and Kısat, N. Ç. (2016). Yöneticilerin etik liderlik davranışlarının, örgütsel adalet ve sinizm üzerine etkileri: Çanakkale İl Emniyet Müdürlüğü'nde bir araştırma, Yönetim Bilimleri Dergisi, 14 (28): 483-509.

Akova, O and Işık, K. (2008). Otel işletmelerinde stres yönetimi: İstanbul'daki beş yıldızlı otel işletmelerinde bir araştırma, Kocaeli Üniversitesi Sosyal Bilimler Enstitüsü Dergisi, (15) 1, 17-44.

Bağcı, Z. and Akbaş, T. T. (2018). Etik liderlik davranışlarının çalışanların örgütsel adalet algıları üzerindeki etkisini belirlemeye yönelik bir araştırma, Journal of Social and Humanities Sciences Research (JSHSR), 5 (25): 1927-1935.

Bies, RJ. and Moag, JS. (1986). Interactional justice: communication criteria of fairness, research on negotiation in organizations, $1(1)$ : 43-55.

Bolat, T., and Seymen, O. A. (2003). Örgütlerde iş etiği ve kariyer yönetimi ilişkisi: Normatif etik boyutlarıyla bir değerlendirme, İşletme İktisadı Enstitüsü Yönetim Dergisi, 14 (45), 3- 19. 
Brown, M. E., Treviño, L. K., and Harrison, D. A. (2005). Ethical leadership: A social learning perspective for construct development and testing, Organizational Behavior and Human Decision Processes, 97, 117134.

Ciulla, J. B. (2005). The state of leadership ethics and the work that lies before us, Business Ethics: A European Review, 14 (4): 323-335.

Conaway, R. N. and Fernandez, T. L. (2000). Ethical preferences among business leaders: 1mplication for business schools, Business Communication Quarterly, 63(1): 23-31.

Çıraklı, Ü. , Uğurluoğlu, Ö. , Şantaş, F. and Çelik, Y. (2014). Etik liderlik davranışlarının örgütsel adalet üzerindeki etkisi: hastanede bir uygulama, İşletme Bilimi Dergisi, 2 (2): 53-69.

Demir, M. (2011). Effects of organizational justice, trust and commitment on employees' deviant behavior, Anatolia - An International Journal of Tourism and Hospitality Research, Vol. 22, No. 2, August 2011, 204-221.

Erdem, B. (2004). Otel işletmelerinde insan kaynakları planlamasının yeri ve önemi. Balıkesir Üniversitesi Sosyal Bilimler Enstitüsü Dergisi, 7 (11), 35-55.

Greenberg, J. (1990). Organizational justice: yesterday, today, and tomorrow, Journal of Management, 16(2): 399-432.

Haq, S. (2011). Ethics and leadership skills in the public service, Procedia Social and Behavioral Sciences, 15 (2011): 2792-2796.

İçerli, L. (2010). Örgütsel adalet: kuramsal bir yaklaşım, Girişimcilik ve Kalkınma Dergisi, 5(1): 67-92.

İnak, A. , Özkoç, A. G. and Kırıcı, E. (2018). Otel işletmelerinde etik liderlik davranışının örgütsel adalet üzerine etkisi, Iğdır Üniversitesi Sosyal Bilimler Dergisi, 14: 286-309.

İşbaşı, J. Ö. (2001). Çalışanların yöneticilerine duydukları güvenin ve örgütsel adalete ilişkin algılamalarının vatandaşlık davranışının oluşumundaki rolü, Yönetim Araştırmaları Dergisi, 1, 51-73.

İşcan, Ö. F., and Naktiyok, A. (2004). Çalışanların örgütsel bağdaşımlarının belirleyicileri olarak örgütsel bağlılık ve örgütsel adalet algıları, Ankara Üniversitesi Siyasal Bilgiler Fakültesi Dergisi, 59(1), 181201.

Jahangir, N., Akbar, M., and Begum, N. B. (2006). The role of social power, procedural justice, organizational commitment, and job satisfaction to engender organizational citizenship behavior, ABAC Journal, 26 (3): 21-36.

Khuong, M. N. and Quoc, T. H. (2016). The effects of organizational justice and ethical leadership on employee performance in Binh Duong's Industrial Parks, Vietnam. Journal of Economics, Business and Management, 4 (4): 327-333.

Kim, W. G. and Brymer, R. A. (2011). The effects of ethical leadership on manager job satisfaction, commitment, behavioral outcomes and firm performance, International Journal of Hospitality Management, 30 (2011): 1020-1026.

Kurgun, O. A. , Aktaş, E. and Güripek, E. (2013). Çalışanların örgütsel adalet algılarında yöneticilerinin etik liderlik davranışlarının rolü, Balıkesir Üniversitesi Sosyal Bilimler Enstitüsü Dergisi, 16 (30): 151-166.

Kültür ve Turizm Bakanlığı, 2018.

Luria, G. and Yagil, D. (2008). Procedural justice, ethical climate and service outcomes in restaurants, International Journal of Hospitality Management, 27 (2008): 276-283.

Mayer, D. M., Kuenzi, M., Greenbaum, R., Bardes, M., and Salvador R. (2009). How low does ethical leadership flow? Test of a trickle- down model, Organizational Behavior and Human Decision Processes, 108 (2009): 1-13. 
C. M. Koçoğlu - Y. Yumuk 11/1 (2019) 337-346

Mayer, D. M., Aquino, K., Greenbaum, R. L. and Kuenzi, M. (2012). Who displays ethical leadership, and Why does it matter? An examination of antecedents and consequences of ethical leadership. Academy of Management Journal, 55(1): 151-171.

Meydan, C.H., Şeşen, H., and Basım. H.N. (2011). Adalet algısı ve tükenmişliğin örgütsel vatandaşlık davranışları üzerindeki öncüllük rolü, “İşGüçc" Endüstri İlişkileri ve İnsan Kaynakları Dergisi, 13 (2), 41-62.

Niehoff, Brian P. ve Robert H. Moorman (1993). Justice as a Mediator of the Relationship between Methods of Monitoring and Organizational Citizenship Behavior, The Academy of Management Journal, 36(3): 527-556.

Öktem, Ş. (2013). The effect of the ethical leadership on perceived organizational justice and organizational identification of the employees: The case of tourism businesses, Journal of Tourism and Gastronomy Studies, 1(3): 10-21.

Parker, R. J and Kohlmeyer, J. M. (2005). Organizational justice and turnover in public accounting firms: A research note, Accounting, Organizations and Society, 30 (4): 357-369.

Peterson, Debra. K. (2002). The relationship between unethical behavior and the dimensions of the ethical climate questionnaire, Journal of Business Ethics, Cilt: 41, 313- 326.

Pillai, R., Scandura, T. A. and Williams, E. A. (1999). Leadership and organizational justice: similarities and differences across cultures, Journal of International Business Studies, 30(4): 763-779.

Scherer, R. Wiebe, F..A., Luther, D.C. \& Adams,J.S. (1988). Dimensionality of coping: Factor stability using the ways of coping questionnaire, Psychological Report, 62, 763-770.

Searle, R.H., \& Ball, K.S. (2004). The development of trust and distrust in a merger. Journal of Managerial Psychology, 19, 708-721.

Sekaran, U. (2003). Research Methods for Business, John Wiley High Education Press: New York, ABD.

Simons, T. L. and Roberson, Q. (2003). Why managers should care about fairness: The effects of aggregate justice perceptions on organizational outcomes, Journal of Applied Psychology, 88: 432-443.

Tang, G., Cai, Z. , Liu, Z. , Zhu, H. , Yang, X. and Li, J. (2015). The importance of ethical leadership in employees' value congruence and turnover, Cornell Hospitality Quarterly, 56 (4): 397-410.

Taylor, A. J. W. (2003). Justice as a basic human need, New Ideas in Psychology, 21(3): 209-219.

Thoms, J. C. (2008). Ethical integrity in leadership and organizational moral culture, Leaderhip, 4 (4): 419439.

$\mathrm{Wu}, \mathrm{X}$. and Wang, C. (2008). The impact of organizational justice on employees' pay satisfaction, work attitudes and performance in Chinese Hotels, Journal of Human Resources in Hospitality \& Tourism, 7(2): 181-195.

Yeşiltaş, M., Çeken, H. and Sormaz, Ü. (2012). Etik liderlik ve örgütsel adaletin örgütsel sapma davranışları üzerindeki etkisi, Muğla Üniversitesi Sosyal Bilimler Enstitüsü Dergisi, 28 (2012): 18-39.

Yumuk, Y. (2018). Otel işletmelerinde birey-örgüt uyumu örgütsel yabancılaşma ilişkisinde örgüt kültürünün rolü. Doktora Tezi, Dokuz Eylül Üniversitesi Sosyal Bilimler Enstitüsü, İzmir.

Zhu, W., May, D. R. and Avolio, B. J. (2004). The impact of ethical leadership behavior on employee outcomes: The roles of psychological empowerment and authentcity, Journal of Leadership \& Organizational Studies, 11(1): 16-26. 